\title{
AN EMPIRICAL INVESTIGATION OF CONSUMPTION BEHAVIOUR IN SELECTED OIC COUNTRIES
}

\author{
Salman Ahmed Shaikh ${ }^{1}$ \\ Mohd Adib Ismail ${ }^{2}$ \\ Abdul Ghafar Ismail ${ }^{3}$ \\ Shahida Shahimi ${ }^{4}$ \\ Muhammad Hakimi Mohd. Shafiai ${ }^{5}$
}

\begin{abstract}
This study examines the consumption behaviour in Organization of Islamic Cooperation (OIC) countries. It presents empirical evidence on rational expectations permanent income hypothesis (RE-PIH) and tests whether the phenomena of myopia, liquidity constraints or loss aversion impede forward-looking consumption behaviour. It also attempts to measure the intertemporal elasticity of substitution. The empirical evidence defies the existence of consumption smoothing phenomena as postulated in RE-PIH. The results support loss aversion. The response of consumption to unexpected income changes is statistically significant in only one-third of the countries. In contrast, the response of consumption to expected income changes is statistically as well as economically significant in as many countries. The intertemporal elasticity of substitution is also statistically insignificant in most of the countries and the elasticity is generally not positive. For the Islamic finance industry, the results help in explaining the low penetration of equity-based risk sharing instruments. From the policy perspective, the excess sensitivity of consumption to income suggests that redistribution efforts to enhance incomes of poor could help in enhancing their consumption levels.
\end{abstract}

Keywords: Myopia, Liquidity Constraints, Loss Aversion, Intertemporal Elasticity of Substitution JEL Classification: E21, E44, G1

Received : August 22, 2017

Revised : August 03, 2018

Accepted : August 06, 2018

1. Assistant Professor at SZABIST Karachi. Email: salman@siswa.ukm.edu.my.

2. Senior Lecturer at Universiti Kebangsaan Malaysia.

3. Professor of Islamic Financial Economics at Universiti Islam Sultan Sharif Ali.

4. Associate Professor and Head of Postgraduate Programs at Universiti Kebangsaan Malaysia.

5. Senior Lecturer at Universiti Kebangsaan Malaysia. 


\section{INTRODUCTION}

Generally, people desire to have smooth lifetime consumption. At the very start and back end of their lives, people in their non-working age usually have no or lower incomes. In the middle period of a lifetime, people are able to generate income from labour supply. They can make financial investments if income minus consumption leaves surplus endowments. The return on these investments can help them accumulate resources for retirement and to leave bequests. However, in all periods of life, people require consistent consumption.

Even in an Islamic framework, the consumer would want to achieve lifetime consumption smoothing in a relatively similar 'smooth' pattern. The difference comes in the choice of income generation and income allocation processes. A Muslim consumer with net endowment surplus has to follow certain restrictions in intertemporal consumption choices. For instance, Islamic principles prohibit Riba (interest), Gharar (uncertainty in speculative trades), Maysir (gambling) and certain sale transactions which do not fulfill the requirements of delivery, possession and specification of price. Hence, a Muslim consumer will have a different choice of investible assets and a limited set of trading strategies within which to make intertemporal consumption choices.

Furthermore, other factors may restrict the individuals to achieve consumption smoothing. For instance, if the income itself is not smooth and the financial services are not accessible to the masses; then, despite having the desire to achieve lifetime consumption smoothing, it may remain elusive for people with binding liquidity constraints. Low levels of income leave little surplus and savings. Hence, consumption may remain dependent on current incomes which can be highly volatile for informal industrial workers and farmers. In countries like Burkina Faso, Sierra Leone, Uganda, Niger and Bangladesh, the share of agriculture employment as a proportion of total employment stands at $84 \%, 68 \%, 65 \%, 56 \%$, $48 \%, 44 \%$ and $43 \%$ respectively.

On the other hand, voluntary exclusion from financial services can create liquidity constraints. Muslims are significantly less likely than non-Muslims to own a formal account or save at a formal interest based financial institution after controlling for other individual and country-level characteristics (Demirgüç-Kunt et al., 2013). In countries like Afghanistan, Morocco, Iraq, Niger and Djibouti, the percentage of adult population with no bank accounts for religious reasons stands at $33.6 \%, 26.8 \%, 25.6 \%, 23.6 \%$ and $22.8 \%$, respectively.

On the positive side, Akerlof (2007) suggests that social norms could provide motivation for actions. There is strong incentive mechanism for pure altruism in Islamic worldview. Islamic principles make every wealthy Muslim liable to share a portion of his/her wealth with the poor in society. Thus, altruism and philanthropic endowments provide a social safety net to the poor and needy. Thus, some of the liquidity constrained poor households could find necessary support from social finance even if they are unable to access the formal financial institutions and remain underserved by weakly funded public support programs (Jappelli \& Pistaferri, 2010).

Thus, these distinct characteristic features of OIC countries make it interesting to explore consumption behaviour in OIC countries. This study explores the consumption behaviour in selected OIC countries by examining the evidence 
for forward-looking consumption behaviour and the strength of intertemporal elasticity of substitution. Finally, this study investigates the response in consumption due to expected and unexpected income changes to investigate the excess sensitivity and excess smoothness phenomena in OIC countries.

\section{LITERATURE REVIEW}

In consumer theory, Absolute Income Hypothesis (AIH) is a pioneer attempt to explain consumption behaviour. AIH postulates that consumption is a function of current income and that marginal propensity to consume (MPC) is positive but less than 1. As a result, average propensity to consume (APC) would fall with successive increases in income (Keynes, 1935). The economic implication is that in response to an increase in income; richer households would relatively save more than the poorer households. Early cross-sectional studies and short-term time series results gave credence to this hypothesis (Williams \& Zimmerman; Stigler, 1954). Even contemporary empirical cross-sectional studies, such as by Lusardi (1992) and Souleles (1995) also find similar results and conclude that the MPC is considerably higher for consumers with low wealth or low income as compared to consumers with high wealth or high income. Murugasu et al. (2013) in a study for Malaysia find that the MPC for lower income groups is higher than the MPC for higher income households. Jappelli and Pistaferri (2014) provide empirical evidence from Italy which shows that households with low cash-on-hand exhibit a much higher MPC than affluent households.

Nevertheless, the long-term time series data defied the proposition of falling APC (Kuznets et al., 1946). Hence, to reconcile cross-sectional and long-term time series evidence, economists tried to build micro-foundations for the consumer behaviour. To build the theoretical foundation on this vision, it was posited that the consumer behaves in an intertemporal context whereby his consumption is a function of lifetime resources and not just current income (Fisher, 1930). Permanent income hypothesis (PIH) contends that consumption is a function of permanent income (Friedman, 1957). Changes in permanent income would affect consumption, but changes in transitory income would mostly be saved (Friedman, 1957). In the lifecycle consumption hypothesis (LCH), the consumption is based on lifetime resources (Modigliani \& Brumberg, 1954; Ando \& Modigliani, 1963). Since then, this brand of research has stimulated exciting ideas, especially after the Lucas (1976) critique and increased emphasis on micro-foundations in modern macroeconomics.

To empirically test the implications of PIH, Hall (1978) contends that consumption is a random walk. Hall's (1978) random walk hypothesis implies that unexpected changes in permanent income can affect current consumption, but expected changes in income do not have any explanatory power. Later empirical studies tested Hall's random walk hypothesis, but they found contradictory evidence. Flavin (1981) observes that changes in current income have explanatory power and termed such phenomenon as "excess sensitivity of consumption" (Flavin, 1985). Other studies in this brand of research include Hayashi (1982), Bernanke (1985), Campbell and Mankiw (1990) and Shea (1995). Campbell and Mankiw (1990) show that in an economy, consumers can satisfy both AIH and 
PIH simultaneously. Some fraction of the consumers can be forward-looking consumers and some fraction of the consumers may simply spend their current income. Their estimates show that roughly half of the consumers do not exhibit forward-looking consumption behaviour. Roche (1995) also find that PIH holds for only about $50 \%$ of the consumers. Virad (1997) confirms that the empirical evidence supports excess sensitivity of consumption to current disposable income, rather than to time-varying real interest rates or non-separable utility. Later studies explain the reasons for the rejection of PIH. Flavin (1985), Zeldes (1989) and Japelli and Pagano (1989) identify liquidity constraints as one possible reason while Runkle (1991) identify myopia as the reason why PIH fails in real-world consumer behaviour. Deaton (1991) argues that most households exhibit buffer-stock saving behaviour while Wolff (1998) contends that most households have little wealth. Shea (1995) finds evidence of loss aversion for the United States.

In a cross-country research, Bowman et al. (1999) present evidence supporting loss aversion from OECD countries. Juan and Seater (1997) conclude from their cross-country test of PIH that data from industrial countries support PIH, but data from developing countries does not. Olekalns (1997) establishes that PIH is rejected in Australia due to liquidity constraints for the period in which the financial system was regulated. Drakos (2002) documents the empirical failure of the PIH in Greece. The empirical findings imply that this failure is due to the presence of liquidity constraints rather than myopia. Gomes and Paz (2010) test the PIH for Brazil, Colombia, Peru and Venezuela. They find that liquidity constraints explain the failure of PIH in Brazil and Colombia, while loss aversion explains the failure of PIH in Peru. Thus, despite a solid theoretical foundation, there has been mixed evidence on PIH.

Among the OIC countries, Khan and Nishat (2011) show the strong validity of AIH rather than PIH for Pakistan. Their evidence points towards the existence of liquidity constraints. Yazdan and Sina (2013) also provide evidence against PIH for Iran. On the other hand, Bilgili and Bagl (2016) establish that consumption in Turkey is responsive to both expected and unexpected income changes. In a cross-country study, Juan and Seater (1997) find that current income innovations lead consumers to revise their current consumption in OIC countries, such as in Algeria, Bangladesh, Comoros, Gabon, Guyana, Indonesia, Iraq, Jordon, Malaysia, Mali, Nigeria, Pakistan, Senegal, Suriname, Syria and Tunisia. However, the data in that study pertains to the very early period when the Muslim majority countries in Central Asia had not gained independence and when Islamic banking did not even exist in most of the Muslim majority countries. For Muslim majority countries, the absence of interest based financial intermediation, high incidence of poverty, high proportion of employment in informal and agricultural occupations and replacement of financial with social institutions warrants an empirical examination of consumption behaviour. This study aims to fulfill that objective. The next section gives an account of the research methodology adopted to fulfill the aims of the study. 


\section{RESEARCH METHODOLOGY}

\subsection{Rational Expectations Permanent Income Hypothesis (RE-PIH) Model}

This study uses the Rational Expectations Permanent Income Hypothesis (RE$\mathrm{PIH}$ ) for analyzing consumption behaviour since this model is microfounded and incorporates forward-looking intertemporal consumption behaviour. Below, a brief mathematical presentation of the model is provided. The representative consumer maximizes the following utility function:

$$
\operatorname{Max} \mathrm{E}_{\mathrm{t}} \sum_{\mathrm{i}=0}^{\mathrm{T}-\mathrm{t}}(1+\rho)^{-\mathrm{i}} \mathrm{U}\left(\mathrm{C}_{\mathrm{t}+\mathrm{i}}\right) \quad, \mathrm{U}^{\prime}>0, \mathrm{U}^{\prime \prime}<0
$$

$$
\text { Subject to: } \sum_{\mathrm{i}=0}^{\mathrm{T}-\mathrm{t}}(1+\mathrm{r})^{-\mathrm{i}}\left(\mathrm{C}_{\mathrm{t}+\mathrm{i}}-\mathrm{Y}_{\mathrm{t}+\mathrm{i}}\right)=\mathrm{A}_{\mathrm{t}}
$$

Where,

$\mathrm{C}_{\mathrm{t}}=$ Private consumption at period $\mathrm{t}$.

$E_{t}=$ Expectations formed subject to information at period $t$.

$\mathrm{T}=$ Total time period of life.

$\mathrm{Y}_{\mathrm{t}}=$ Disposable labour income at period $\mathrm{t}$.

$A_{t}=$ Lifetime resources excluding human capital at period $t$.

Q $\quad$ = Rate of subjective time preference.

$\mathrm{r} \quad=$ Rate of profit.

$u^{\prime}>0$ implies that the marginal utility of consumption is positive and $u^{\prime \prime}<0$ implies diminishing marginal utility. It is assumed that households can invest and access finance at the markup rate $r$. The standard Euler equation from the maximization of the utility function yields:

$$
E_{t} u^{\prime}\left(C_{t+1}\right)=\left(\frac{1+\delta}{1+r}\right) u^{\prime}\left(C_{t}\right)
$$

It is further assumed that $r=\delta$. If the marginal utility $u^{\prime}$ is linear or log linear, then an interesting result appears in which current consumption is the best forecast of future consumption in the next period, i.e.:

$$
C_{t+1}=C_{t}+e_{t}
$$

If expectation is taken on both sides, it becomes:

$$
E_{t} C_{t+1}=C_{t}
$$

It is because of $E\left[e_{t}\right]=0$

Using equation (3), it can be shown that consumption is a random walk.

$$
C_{t+1}-C_{t}=e_{t}
$$


$\Delta C_{t}=e_{t}$

To test the PIH, the following empirical model is used:

$$
\Delta C_{t}=\alpha+\lambda \Delta Y_{t}+e_{t}
$$

Where,

$C_{t} \quad=$ Natural log of household real consumption per capita.

$\Delta C_{t} \quad=$ The Growth rate of household real consumption per capita.

$Y_{t} \quad=$ Natural log of real Zakat adjusted income per capita.

$\Delta Y_{t} \quad=$ The Growth rate of real Zakat adjusted income per capita.

Previous studies in OIC countries have not adjusted the budget constraint for Zakat. This study incorporates this adjustment by deducting $2.5 \%$ of real per capita income as Zakat from the unadjusted real per capita income. As per REPIH model, changes in current income shall not determine current consumption. If $\lambda=0$, then, PIH will be satisfied. Campbell and Mankiw (1990) also control for time variation in in the terest rate. Then, the extended model becomes:

$$
\Delta C_{t}=\mu+\delta \Delta Y_{t}+\theta r_{t}+e_{t}
$$

Where $r_{t}$ is the real profit rate in period $t$.

Under the phenomenon of myopia, the myopic consumers consume a fixed share of current income. Therefore, consumption should respond symmetrically to the increases as well as decreases in expected income. On the other hand, if liquidity constraints are binding, individual consumption should respond more strongly to the increase in expected income than to the decrease in expected income. The asymmetrical behaviour under binding liquidity constraints restricts individuals from borrowing, especially when incomes are declining. However, they can save freely in all periods. Under loss aversion, people tend to avoid the risk of loss. Using the methodology adopted by Shea (1995), the presence of liquidity constraints, myopia or loss aversion is tested by using the following regression model:

$$
\Delta C_{t}=\tau+\lambda_{1}(P O S) \Delta Y_{t}+\lambda_{2}(N E G) \Delta Y_{t}+\sigma r_{t}+e_{t}
$$

Here, POS and NEG are dummy variables. POS takes the value of 1 when income changes are positive and zero otherwise. NEG takes the value of 1 when income changes are negative and zero otherwise. Table 1 summarizes the testable hypotheses. 
Table 1.

Testable Hypotheses

\begin{tabular}{lc}
\hline \multicolumn{1}{c}{ Conjectures } & Validation Criteria \\
\hline RE-PIH Holds & $\lambda_{1}=\lambda_{2}=0$ \\
RE-PIH Fails Due to Myopia & $\lambda_{1}=\lambda_{2}$ \\
& $\lambda_{1}>0, \lambda_{2}>0$ \\
RE-PIH Fails Due to Liquidity Constraints & $\lambda_{1}>\lambda_{2}$ \\
& $\lambda_{1}>0, \lambda_{2}>0$ \\
RE-PIH Fails Due to Loss Aversion & $\lambda_{1}<\lambda_{2}$ \\
& $\lambda_{1}>0, \lambda_{2}>0$ \\
\hline
\end{tabular}

In addition to that, Flavin's (1981) empirical approach is used to explore the response in consumption due to expected and unexpected income changes. The following model specification is used to test for this conjecture for each of the countries.

$$
\Delta C_{t}=\varphi_{0}+\varphi_{1} C_{t-1}+\varphi_{2}\left(Y_{t}-E Y_{t}\right)+\varphi_{3} E Y_{t}+\mu_{t}
$$

Here, $\Delta C_{t}$ is the difference in log of real consumption. $E Y_{t}$ is an estimate of expected income. $Y_{t}-E Y_{t}$ is an estimate of unexpected income. RE-PIH implies that consumption shall only respond to the unexpected changes in income and not to the expected changes in income. If $\varphi_{2}$ is statistically significant while $\varphi_{3}$ is statistically insignificant, then this result would be consistent with RE-PIH. If $\varphi_{3}$ is statistically significant, it implies that there is 'excess sensitivity' in consumption with regards to changes in expected income. If $\varphi_{2}$ is insignificant, it implies that there is 'excess smoothness' in consumption since it does not change even due to unexpected changes in income.

Finally, the intertemporal elasticity of substitution is computed by using Hall's (1988) approach. The elasticity of intertemporal substitution can be estimated as the response of rate of change of consumption to changes in the real rate of return. If the intertemporal elasticity of substitution is indistinguishable from zero, then it would imply that the net effect of changes in real returns on consumption is negligible.

\subsection{Data Collection}

The data for this study is obtained from the World Development Indicators 2015. The period of study is 1970-2013. In total, 32 OIC member countries are selected where data is sufficiently available.

\subsection{Research Methods}

Standard econometric tools and testing procedures are used to account for stationarity and autocorrelation. For panel data analysis, the Hausman test is 
used to decide between fixed effects and random effects model. Panel unit root is checked using Im-Pesaran-Shin test and Fisher-type tests. For time series data, the unit root is checked using Augmented Ducky-Fuller (ADF), Phillips Perron and Dickey Fuller-Generalized Least Squares (DF-GLS) tests.

Using the different instruments list, Two-Stage Least Squares (2SLS) Instrumental Variable (IV) regression, Limited Information Maximum Likelihood (LIML) and Generalized Method of Moments (GMM) estimation frameworks are employed. Over-identifying restrictions are tested using Sargan's and Basmann's chi-square tests for 2SLS, Anderson-Rubin likelihood-ratio test and Basmann's F test for LIML and Hansen's J statistic for GMM. The instruments lists of Campbell and Mankiw (1990) are used to account for the endogeneity problem in estimation. The variables used in various instruments lists are mentioned in Table 2 below.

Table 2.

Instruments Lists Used in Estimation

\begin{tabular}{|c|c|}
\hline Instrument List & Instrument Variables \\
\hline 1 & $\Delta \mathrm{Y}_{\mathrm{t}-2^{\prime}} \Delta \mathrm{Y}_{\mathrm{t}-\mathrm{y}^{\prime}} \Delta \mathrm{Y}_{\mathrm{t}-\mathrm{y}^{\prime}} \Delta \mathrm{Y}_{\mathrm{t}-\mathrm{j}^{\prime}} \Delta \mathrm{Y}_{\mathrm{t}-6}$ \\
\hline 2 & $\Delta \mathrm{C}_{\mathrm{t}-2^{2}} \Delta \mathrm{C}_{\mathrm{t}-3^{3}} \Delta \mathrm{C}_{\mathrm{t}-\mathrm{y}^{\prime}} \Delta \mathrm{C}_{\mathrm{t}-\mathrm{r}^{\prime}} \Delta \mathrm{C}_{\mathrm{t}-6}$ \\
\hline 3 & $\Delta \mathrm{i}_{\mathrm{t}-2^{\prime}} \Delta \mathrm{i}_{\mathrm{t}-3^{\prime}} \Delta \mathrm{i}_{\mathrm{t}-4^{\prime}} \Delta \mathrm{i}_{\mathrm{t}-5^{\prime}} \Delta \mathrm{i}_{\mathrm{t}-6}$ \\
\hline 4 & $\Delta \mathrm{Y}_{\mathrm{t}-2^{2}} \Delta \mathrm{Y}_{\mathrm{t}-3^{3}} \Delta \mathrm{Y}_{\mathrm{t}-\mathbf{y}^{\prime}} \Delta \mathrm{C}_{\mathrm{t}-2^{2}} \Delta \mathrm{C}_{\mathrm{t}-3^{\prime}} \Delta \mathrm{C}_{\mathrm{t}-4}$ \\
\hline 5 & 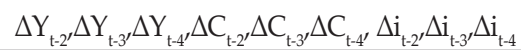 \\
\hline
\end{tabular}

For examining the response in consumption due to expected and unexpected income changes, time series of expected and unexpected income changes is estimated. For generating expected income series, Autoregressive Integrated Moving Average (ARIMA) is applied with a suitable identification scheme for each of the OIC countries.

\section{EMPIRICAL RESULT AND ANALYSIS}

This section presents and analyzes the empirical findings. The estimates from panel data regression of equation (7), (8) and (9) appear in Table 3 in Appendix. The empirical evidence challenges the existence of consumption smonthing nhenomena as postulated in PIH. The estimated coefficients on income $\left(\lambda, \lambda_{1}\right.$ and $\left.\lambda_{2}\right)$ are positive and statistically significant in all estimation frameworks. Support for the phenomenon of mynnia or liquidity constraints is also not found. Since the estimated coefficient on $\lambda_{1}$ is generally not equal to $\lambda_{2}$, it is concluded that the houceholds in OIC countries are not myopic. On the other hand, the coefficient on $\lambda_{1}$ is generally lower than ${ }^{\lambda_{2}}$ which implies that the households do not deviate from consumption smoothing because of liquidity constraints. However, the evidence supports the phenomenon of loss aversion.

Under loss aversion, when people receive good news about expected rise in the income, they adjust current consumption upward immediately, thereby reducing 
the possibility of a further increase in future consumption. On the other hand, when people receive bad news about expected fall in income, they do not change current consumption, thereby enhancing the possibility of slide in future consumption if this expectation is realized (Treeck, 2010; Johansson, 2002). Shea (1995) explains that loss-averse households may refuse to reduce consumption today in the face of expected, but uncertain declines in future income. Consumers with such preferences suffer large psychic losses when forced to cut living standards. Bowman et al. (1999) explain that when people get accustomed to a particular level of consumption, they feel a greater sense of loss when they are deprived to achieve the reference point consumption level. Treeck (2010) explains that if consumers engage in conspicuous consumption, then they may delay lowering consumption 'to keep up with the Joneses'. Nonetheless, when the income actually does decline, they are forced to change their consumption. On the other hand, Gomes (2014) explains that loss aversion can be interpreted as uncertainty aversion whereby uncertainty is higher when income falls.

Prospect theory also explains this phenomenon as people feel more strongly about the pain from a loss than the pleasure from an equal amount of gain (Kahneman and Tversky, 1979). Perez (2000) provides an alternate explanation by assuming that income increases consistently until retirement, but there is no income after retirement. He further assumes that the expected increase in income can relax liquidity constraints, but an expected decrease in income cannot. In that case, if the consumer faces liquidity constraints in youth while expecting an increase in income in subsequent years until retirement, then he will save during youth and may not increase his consumption as much. This can explain the quantitatively lesser coefficient for the expected increase in income as compared to the coefficient for the expected decrease in income.

From the Islamic finance industry perspective, loss aversion can possibly explain the nature of financial intermediation in OIC countries as they rely mostly on a less risky bank-based finance as compared to capital markets. Benartzi and Thaler (1995) contend that loss aversion can explain under-investment in risky assets. It can also partially explain why the actual use of equity-based modes of financing is lower in OIC countries despite the ideological preference for these modes. The results can provide a behavioral explanation of why equity financing with the high risk-high return is less preferred in commercial product offerings. It is because the consumers have high loss aversion due to which they put greater weight on negative losses than on the positive gains in intertemporal consumption choices. That is why, Islamic banks as agents and delegated monitors for lossaverse Muslim savers predominantly use less-risky Shari'ah compliant financing contracts. Loss aversion implies that it would be better to target redistribution through social finance institutions like Zakat, Waqf and Qard-e-Hassan since commercial finance institutions would be hesitant to use equity financing instruments given high loss aversion.

Table 4 in Appendix presents the results of equation (10). In 11 out of 28 countries where the data is available for at least since 1990, consumption does respond to expected income. This is against the intuition implied by PIH. As per $\mathrm{PIH}$, consumption should only respond to unanticipated income changes and not to expected income changes. In 10 out of 28 countries where the data is available 
for at least since 1990, consumption responds to unexpected income changes. In relatively developed OIC countries like Malaysia and Turkey where the financial outreach is considerably more widespread, and incidence of poverty is lower, the consumption responds to unexpected income changes and not to expected income changes.

Finally, Table 5 in Appendix gives the estimates of the intertemporal elasticity of substitution. The results suggest that in most countries, the consumption does not respond to the real rate of return. In 2 of the 4 countries where the intertemporal elasticity of substitution is significant, the estimate is negative, i.e. -0.35 and -0.17 in Bangladesh and Pakistan respectively. In 2 of the other 4 countries where the intertemporal elasticity of substitution is significant, the estimate is positive, but significantly less than 1, i.e. 0.16 and 0.37 in Lebanon and Guyana respectively. In other countries, the estimate of the intertemporal elasticity of substitution is not significant. Havránek (2015) reviews 169 studies and concludes that the mean estimate is near zero. For OIC countries, these results are plausible since most of the OIC countries are poor countries where the majority of the population does not have enough wealth to engage in forward-looking intertemporal consumption behaviour. Guvenen (2000) explains that such results appear because consumption is much more evenly distributed across households than is wealth. Poor households are in majority and these poor households usually do not have surplus resources to invest and thus, changes in real returns do not affect their behaviour significantly.

\section{CONCLUSION}

The evidence presented in this study challenges the existence of consumption smoothing phenomena as postulated in permanent income hypothesis (PIH). The evidence suggests that loss aversion impedes forward-looking consumption behaviour. Furthermore, in several countries, the consumption responds to expected income changes, which is against the intuition implied by PIH. The intertemporal elasticity of substitution is also statistically insignificant in most of the OIC countries and there is no strong evidence that the elasticity is generally positive. The phenomenon of loss aversion could explain the low penetration of equity-based risk-sharing instruments. The excess sensitivity of consumption to income suggests that redistribution efforts to enhance incomes of poor households could help in enhancing their consumption levels. Thus, income redistribution and financial inclusion policies could be effective in enabling the households to smooth incomes and subsequently consumption.

\section{REFERENCES}

Akerlof, G. A. (2007). The Missing Motivation in Macroeconomics, American Economic Review, 97(1), 5 - 36.

Ando, A. \& Modigliani, F. (1963). The 'Life Cycle' Hypothesis of Saving: Aggregate Implications \& Tests, American Economic Review, 55 - 84.

Benartzi, S. \& Thaler, R. (1995). Myopic Loss Aversion and the Equity Premium Puzzle, Quarterly Journal of Economics, 110, 73 - 92.

Bernanke, B. S. (1985). Adjustment Costs, Durables and Aggregate Consumption, Journal of Monetary Economics, 15(1), 41 - 68. 
Bilgili, F., \& Bagl, H. H. (2016). Testing the Permanent Income and Random Walk Hypotheses for Turkey. International Journal of Economics and Financial Issues, 6(4), $1371-1378$.

Bowman, D.; Minehart, D. \& Rabin, M. (1999). Loss Aversion in a SavingsConsumption Model, Journal of Economic Behaviour and Organization, 38, 155 -178 .

Campbell, J. \& Mankiw, N. (1990). Permanent Income, Current Income, and Consumption, Journal of Business and Economic Statistics, 8(3): 265 - 279.

Deaton, A. (1991). Saving and Liquidity Constraints. Econometrica, 59(5): 1221 1248.

Demirgüç-Kunt, A., Klapper, L., \& Douglas, R. (2013). Islamic Finance and Financial Inclusion: Measuring Use of and Demand for Formal Financial Services among Muslim Adults. Policy Research Working Chapter No. 6642.

Drakos, K. (2002). Myopia, Liquidity Constraints, and Aggregate Consumption: The Case of Greece, Journal of Economic Development, 27(1): 97 - 105.

Empirical Investigation, The Journal of Political Economy, 97(2): 305 - 334.

Fisher, I. (1930). The Theory of Interest. New York: MacMillan.

Flavin, M. (1985). Excess Sensitivity of Consumption to Current Income: Liquidity Constraints or Myopia, Canadian Journal of Economics, 18, 136 - 177.

Flavin, M. A. (1981). The Adjustment of Consumption to Changing Expectation about Future Income, The Journal of Political Economy, 89(5), $974-1009$.

Friedman, M. (1957). Introduction to a Theory of the Consumption Function. In A Theory of the Consumption Function, 1 - 6. Princeton University Press.

Gomes, F. A. R. (2014). A Note on Uncertainty in Savings Decisions: Can a Naïve Strategy Be Optimal? Macroeconomic Dynamics, 18, 1428 - 1435.

Gomes, F. A. R. \& Paz, L. S. (2010). Consumption in South America: Myopia or Liquidity Constraints?, Economia Aplicada, 14(2), 129 - 145.

Guvenen, M. F. (2000). Mismeasurement of the Elasticity of Intertemporal Substitution: The Role of Limited Stock Market Participation (No. 2000-E26). Carnegie Mellon University, Tepper School of Business.

Hall, R. E. (1978). Stochastic Implications of the Life Cycle-Permanent Income Hypothesis: Theory and Evidence, The Journal of Political Economy, 86, 971 987.

Havránek, T. (2015). Measuring Intertemporal Substitution: The Importance of Method Choices and Selective Reporting, Journal of the European Economic Association, 13, 1180 - 1204.

Hayashi, F. (1982). The Permanent Income Hypothesis: Estimation and Testing by Instrumental Variables, The Journal of Political Economy, 90(5), 895 - 916.

Jappelli, T. \& Pagano, M. (1989). Consumption and Capital Market Imperfections: An Intertemporal Comparison, American Economic Review, 79, 1088 - 1105.

Jappelli, T., \& Pistaferri, L. (2010). The Consumption Response to Income Changes, Annual Review of Economics, 2, 479 - 506.

Jappelli, T. \& Pistaferri, L. (2014). Fiscal Policy \& MPC Heterogeneity, American Economic Journal: Macroeconomics, 6(4), 107 - 136.

Johansson, M. (2002). Re-examining Loss Aversion in Aggregate Consumption: Swedish and International Evidence. Lund University.

Juan, J. P. D. \& Seater, J. J. (1997). A Cross Country Test of the Permanent Income Hypothesis, International Review of Applied Economics, 11(3), 451 - 468. 
Kahneman, D. \& Tversky, A. (1979). Prospect Theory: An Analysis of Decision under Risk. Econometrica, 47(2), 263 - 292.

Keynes, J. M. (1935). The General Theory of Employment, Interest, \& Money, New York: Harcourt Brace \& World.

Khan, K. \& Nishat, M. (2011). Permanent Income Hypothesis, Myopia and Liquidity Constraints: A Case Study of Pakistan, Pakistan Journal of Social Sciences (PJSS), 31(2), $299-307$.

Kuznets, S.; Epstein, L. \& Jenks, E. (1946). Front Matter to National Product Since 1869. In National Product Since 1869. National Bureau of Economic Research.

Lucas, R. E. J. (1976). Econometric Policy Evaluation: A Critique, CarnegieRochester Conferences on Public Policy, 1: $19-46$.

Lusardi, A. (1992). Permanent Income, Current Income, E Consumption: Evidence from Panel Data, Manuscript, Dartmouth College.

Modigliani, F. \& Richard, H. B. (1954). Utility Analysis \& the Consumption Function: An Interpretation of Cross-section Data, in Kenneth K. Kurihara, ed., Post Keynesian Economics, New Brunswick, NJ. Rutgers University Press, 388 - 436.

Murugasu, D.; Wei, A. J. \& Hwa, T. B. (2013). Marginal Propensity to Consume across Household Income Groups. Bank Negara Malaysia, Working Paper No. WP2/2013.

Olekalns, N. (1997). Has Financial Deregulation Revived the Permanent Income/ Life Cycle Hypothesis?, Australian Economic Review, 30(2), 155 - 166.

Perez, S. J. (2000). Myopia, Liquidity Constraints, and Aggregate Consumption: What do the Data Say?, Economics Letters, 67(1), 43 - 48.

Roche, M. J. (1995). Testing the Permanent Income Hypothesis: The Irish Evidence, The Economic and Social Review, 26(3), 283 - 305.

Runkle, D. (1991). Liquidity Constraints and the Permanent Income Hypothesis, Journal of Monetary Economics, 27(1), 73 - 98.

Shea, J. (1995). Myopia, Liquidity Constraints and Aggregate Consumption: A Simple Test, Journal of Money, Credit and Banking, 27(3): 798 - 805.

Souleles, N. S. (1995). The Response of Household Consumption to Income Tax Refunds, Manuscript, Massachusetts Institute of Technology.

Stigler, G. J. (1954). The Early History of Empirical Studies of Consumer Behaviour, The Journal of Political Economy, 62(2): 95 - 113.

Treeck, V. T. (2010). Liquidity Constraints versus Loss aversion in Household Consumption: A Simple Reconciliation (Working Paper No. 13/2010). IMK Working Paper Series.

Viard, A. D. (1997). How Forecastable is Consumption Growth? New Evidence on the Hall Random Walk Hypothesis, Applied Economics, 29(11): 1435 - 1446.

Williams, F. M. \& Zimmerman, C. C. (1935). Studies of Family Living in the United States and Other countries: An Analysis of Material and Method (No. 223). US Department of Agriculture.

Wolff, E. N. (1998). Recent Trends in the Size Distribution of Household Wealth, Journal of Economic Perspectives, 12(3): 131 - 150.

Yazdan, G. F. \& Sina, M. (2013). The Testing of Hall's Permanent Income Hypothesis: A Case Study of Iran, Asian Economic and Financial Review, 3(3): 311 - 318.

Zeldes S. P. (1989). Consumption and Liquidity Constraints: An Empirical Investigation, The Journal of Political Economy, 97(2): 305 - 334. 


\section{APPENDIX 1}

Table 3

Estimation Results for Panel Data of OIC Countries Equation (7,8 and 9)

\begin{tabular}{|c|c|c|c|c|c|c|c|c|c|c|c|c|}
\hline \multirow{2}{*}{$\begin{array}{c}\text { Model } \\
\text { Estimators }\end{array}$} & \multicolumn{3}{|c|}{$\Delta \mathrm{C}_{\mathrm{t}}=\alpha+\lambda \Delta \mathrm{Y}_{\mathrm{t}}+\mathrm{e}_{\mathrm{t}}$} & \multicolumn{4}{|c|}{$\Delta C_{t}=\mu+\delta \Delta Y_{t}+\theta r_{t}+e_{t}$} & \multicolumn{5}{|c|}{$\Delta C_{t}=\tau+\lambda_{1} P \Delta Y_{t}+\lambda_{2} N \Delta Y_{t}+\sigma r_{t}+e_{t}$} \\
\hline & $\alpha$ & $\lambda$ & $\mathbf{R}^{2}$ & $\mu$ & $\delta$ & $\theta$ & $\mathbf{R}^{2}$ & $\tau$ & $\lambda_{1}$ & $\lambda_{2}$ & $\sigma$ & $\mathbf{R}^{2}$ \\
\hline GLS & 0.001 & $.788^{* *}$ & & 0.001 & $.788^{* *}$ & 0.038 & & 0.004 & $.643^{* *}$ & $.896^{* *}$ & 0.031 & \\
\hline MLE & 0.001 & $.788^{* *}$ & & 0.001 & $.788^{* *}$ & 0.037 & & 0.004 & $.642^{* *}$ & $.896^{* *}$ & 0.031 & \\
\hline \multicolumn{13}{|c|}{ Instrumental Variable Regression (Fixed Effects) } \\
\hline IV (1a) & 0.005 & $.609^{* *}$ & 0.47 & -0.014 & $.729^{* *}$ & 0.936 & 0.19 & -0.014 & $.733^{* *}$ & $.722^{* *}$ & 0.952 & 0.19 \\
\hline IV (1b) & & & & -0.372 & $.831^{* *}$ & 0.946 & 0.1 & -0.414 & $.698^{* *}$ & $.929^{* *}$ & 1.06 & 0.1 \\
\hline IV (1c) & & & & -0.004 & $.819^{* *}$ & 0.000 & 0.46 & -0.004 & $.701^{* *}$ & $.900^{* *}$ & 0.000 & 0.45 \\
\hline IV (2a) & 0.001 & $.860^{* *}$ & 0.47 & -0.006 & $.777^{* *}$ & 0.449 & 0.35 & -0.004 & $.716^{* *}$ & $.820^{* *}$ & 0.452 & 0.36 \\
\hline IV $(2 b)$ & & & & -0.353 & $.830^{* *}$ & 0.899 & 0.12 & -0.357 & $.698^{* *}$ & $.925^{* *}$ & 0.916 & 0.12 \\
\hline IV (2c) & & & & -0.025 & $.806^{* *}$ & 0.0001 & 0.26 & -0.019 & $.702^{* *}$ & $.883^{* *}$ & 0.000 & 0.28 \\
\hline IV (3a) & 0.017 & 0.037 & 0.47 & 0.003 & $.835^{* *}$ & -0.134 & 0.44 & 0.006 & $.697^{* *}$ & $.931^{* *}$ & -0.115 & 0.45 \\
\hline IV (3b) & & & & 1.22 & $.792^{* *}$ & -3.08 & 0.0004 & 1.25 & $.709^{* *}$ & $.851^{* *}$ & -3.17 & 0.005 \\
\hline $\operatorname{IV}(3 c)$ & & & & -0.244 & 0.671 & 0.0004 & 0.008 & -0.26 & $.714^{* *}$ & $.625^{* *}$ & 0.001 & 0.007 \\
\hline IV (4a) & -0.001 & $.906^{* *}$ & 0.45 & -0.004 & $.783^{* *}$ & 0.338 & 0.38 & -0.001 & $.691^{* *}$ & $.850^{* *}$ & 0.332 & 0.38 \\
\hline IV (4b) & & & & -0.413 & $.821^{* *}$ & 1.038 & 0.08 & -0.587 & $.659^{* *}$ & $.945^{* *}$ & 1.48 & 0.06 \\
\hline $\operatorname{IV}(4 c)$ & & & & -0.017 & $.803^{* *}$ & 0.000 & 0.31 & -0.015 & $.680^{* *}$ & $.891^{* *}$ & 0.000 & 0.31 \\
\hline IV (5a) & 0.001 & $.828^{* *}$ & 0.45 & -0.002 & $.789^{* *}$ & 0.267 & 0.4 & -0.001 & $.689^{* *}$ & $.861^{* *}$ & 0.275 & 0.41 \\
\hline IV (5b) & & & & -0.401 & $.821^{* *}$ & 1.01 & 0.09 & -0.578 & $.660^{* *}$ & $.945^{* *}$ & 1.46 & 0.06 \\
\hline IV (5c) & & & & -0.018 & $.802^{* *}$ & -0.018 & 0.31 & -0.017 & $.680^{* *}$ & $.889^{* *}$ & 0.000 & 0.29 \\
\hline \multicolumn{13}{|c|}{ Instrumental Variable Regression (GLS Random Effects) } \\
\hline IV (1a) & 0.001 & $.846^{* *}$ & 0.47 & 0.002 & $.822^{* *}$ & -0.027 & 0.47 & 0.006 & $.694^{* *}$ & $.932^{* *}$ & -0.136 & 0.45 \\
\hline IV $(1 b)$ & & & & -0.007 & $.810^{* *}$ & 0.023 & 0.46 & -0.007 & $.680^{* *}$ & $.899^{* *}$ & 0.029 & 0.47 \\
\hline IV (1c) & & & & 0.002 & $.819^{* *}$ & 0.000 & 0.47 & 0.006 & $.695^{* *}$ & $.909^{* *}$ & 0.000 & 0.47 \\
\hline IV (2a) & -0.005 & $1.16^{* *}$ & 0.47 & -0.002 & $.798^{* *}$ & 0.23 & 0.44 & -0.001 & $.707^{* *}$ & $.862^{* *}$ & 0.237 & 0.44 \\
\hline IV $(2 b)$ & & & & -0.038 & $.776^{* *}$ & 0.101 & 0.43 & -0.035 & $.629^{* *}$ & $.882^{* *}$ & 0.103 & 0.44 \\
\hline IV (2c) & & & & -0.041 & $.830^{* *}$ & 0.0001 & 0.16 & -0.04 & $.792^{* *}$ & $.857^{* *}$ & 0.000 & 0.16 \\
\hline IV (3a) & 0.013 & 0.249 & 0.47 & 0.004 & $.832^{* *}$ & -0.138 & 0.44 & 0.006 & $.695^{* *}$ & $.928^{* *}$ & -0.114 & 0.45 \\
\hline IV (3b) & & & & 0.028 & $.849^{* *}$ & -0.069 & 0.46 & 0.028 & $.743^{* *}$ & $.922^{* *}$ & -0.064 & 0.47 \\
\hline IV (3c) & & & & -0.031 & $.827^{* *}$ & 0.000 & 0.22 & -0.037 & $.785^{* *}$ & $.861^{* *}$ & 0.000 & 0.17 \\
\hline IV (4a) & 0.001 & $.822^{* *}$ & 0.45 & 0.001 & $.798^{* *}$ & 0.037 & 0.45 & 0.003 & $.660^{* *}$ & $.897^{* *}$ & 0.058 & 0.46 \\
\hline IV (4b) & & & & 0.004 & $.804^{* *}$ & -0.005 & 0.45 & 0.001 & $.651^{* *}$ & $.906^{* *}$ & 0.008 & 0.46 \\
\hline $\operatorname{IV}(4 \mathrm{c})$ & & & & -0.043 & $.820^{* *}$ & 0.000 & 0.14 & -0.035 & $.742^{* *}$ & $.873^{* *}$ & 0.000 & 0.17 \\
\hline IV (5a) & 0.002 & $.803^{* *}$ & 0.45 & 0.001 & $.795^{* *}$ & 0.073 & 0.45 & 0.002 & $.661^{* *}$ & $.890^{* *}$ & 0.099 & 0.46 \\
\hline IV $(5 b)$ & & & & 0.004 & $.804^{* *}$ & -0.005 & 0.45 & 0.002 & $.653^{* *}$ & $.906^{* *}$ & 0.006 & 0.46 \\
\hline $\operatorname{IV}(5 c)$ & & & & $\begin{array}{l}-0.029 \\
\end{array}$ & $.814^{* *}$ & 0.000 & 0.21 & -0.023 & $.717^{* *}$ & $.884^{* *}$ & 0.000 & 0.25 \\
\hline
\end{tabular}


Table 3: Continued

Estimation Results for Panel Data of OIC Countries Equation (7,8 and 9)

\begin{tabular}{lccccccccccccc}
\hline \multicolumn{10}{c}{ Instrumental Variable Regression (Between Effects) } \\
\hline IV (1a) & 0.002 & $.793^{* *}$ & 0.47 & 0.001 & $.800^{* *}$ & 0.061 & 0.47 & 0.007 & $.644^{* *}$ & $.939^{* *}$ & -0.123 & 0.45 \\
IV (1b) & & & & 0.009 & $.915^{* *}$ & -0.025 & 0.47 & $.014^{* *}$ & $.906^{* *}$ & $1.02^{* *}$ & -0.035 & 0.47 \\
IV (1c) & & & & 0.001 & $.807^{* *}$ & 0.000 & 0.47 & 0.004 & $.658^{* *}$ & $.936^{* *}$ & 0.000 & 0.48 \\
IV (2a) & -0.001 & $.922^{* *}$ & 0.47 & 0.004 & $.797^{* *}$ & -0.11 & 0.44 & 0.007 & $.645^{* *}$ & $.939^{* *}$ & -0.099 & 0.46 \\
IV (2b) & & & & $.020^{* *}$ & $1.06^{* *}$ & $-.058^{* *}$ & 0.47 & $.016^{* *}$ & $.978^{* *}$ & $1.03^{* *}$ & -0.045 & 0.47 \\
IV (2c) & & & & -0.001 & $.824^{* *}$ & -0.001 & 0.47 & 0.001 & $.709^{* *}$ & $.926^{* *}$ & 0.000 & 0.48 \\
IV (3a) & 0.003 & $.786^{* *}$ & 0.47 & 0.005 & $.796^{* *}$ & -0.182 & 0.42 & 0.008 & $.641^{* *}$ & $.940^{* *}$ & -0.174 & 0.43 \\
IV (3b) & & & & 0.005 & $.846^{* *}$ & -0.01 & 0.47 & 0.004 & $.615^{* *}$ & $.928^{* *}$ & 0.005 & 0.47 \\
IV (3c) & & & & -0.009 & $.875^{* *}$ & 0.000 & 0.43 & -0.006 & $.823^{* *}$ & $.903^{* *}$ & 0.000 & 0.45 \\
IV (4a) & 0.004 & $.717^{* *}$ & 0.45 & 0.005 & $.721^{* *}$ & -0.087 & 0.43 & $.010^{* *}$ & $.476^{* *}$ & $.950^{* *}$ & -0.083 & 0.44 \\
IV (4b) & & & & $.033^{* *}$ & $1.17^{* *}$ & $-.09^{* *}$ & 0.45 & $.029^{* *}$ & $1.13^{* *}$ & $1.11^{* *}$ & $-.087^{* *}$ & 0.45 \\
IV (4c) & & & & 0.004 & $.715^{* *}$ & 0.000 & 0.45 & $.009^{* *}$ & $.466^{* *}$ & $.942^{* *}$ & 0.000 & 0.45 \\
IV (5a) & 0.004 & $.719^{* *}$ & 0.45 & 0.005 & $.721^{* *}$ & -0.078 & 0.44 & $.010^{* *}$ & $.478^{* *}$ & $.951^{* *}$ & -0.104 & 0.43 \\
IV (5b) & & & & $.026^{* *}$ & $1.06^{* *}$ & $-.07^{* *}$ & 0.45 & $.025^{* *}$ & $1.01^{* *}$ & $1.08^{* *}$ & $-.07^{* *}$ & 0.46 \\
IV (5c) & & & & 0.004 & $.715^{* *}$ & 0.000 & 0.45 & $.009^{* *}$ & $.469^{* *}$ & $.942^{* *}$ & 0.000 & 0.45 \\
\hline
\end{tabular}

*Statistical significance at $10 \%$ level. **Statistical significance at $5 \%$ level.

IV a) uses real interest rate, IV b) uses labour supply and IV c) uses government real consumption as regressors. Labor supply and government real consumption are used in place of real interest rate to test for nonseparability in the utility function. 
Table 4

Empirical Results for Equation (10) Excess Sensitivity of Consumption

\begin{tabular}{|c|c|c|c|c|c|c|c|}
\hline \multirow{2}{*}{$\begin{array}{c}\text { Model } \\
\text { Country / } \\
\text { Estimators }\end{array}$} & \multirow{2}{*}{$\begin{array}{l}\text { Time } \\
\text { Period }\end{array}$} & \multicolumn{6}{|c|}{$\Delta C_{t}=\varphi_{0}+\varphi_{1} C_{t-1}+\varphi_{2}\left(Y_{t}-E Y_{t}\right)+\varphi_{3} E Y_{t}+\mu_{t}$} \\
\hline & & $\varphi$ & $\varphi_{1}$ & $\varphi_{2}$ & $\varphi_{3}$ & $\begin{array}{c}\text { Adjusted } \\
\mathbf{R}^{2}\end{array}$ & $\begin{array}{l}\text { ARIMA } \\
(p, d, q)\end{array}$ \\
\hline Algeria & 1974-2013 & $-1.06^{* *}$ & $-0.23^{* *}$ & 0.00 & $0.34^{* *}$ & 0.17 & $(1,1,1)$ \\
\hline Bangladesh & 1981-2013 & $3.70^{* *}$ & $-0.45^{* *}$ & $0.00^{* *}$ & -0.23 & 0.37 & $(1,1,1)$ \\
\hline Benin & 1981-2013 & -0.01 & $-1.07^{* *}$ & $-0.00^{* *}$ & $1.06^{* *}$ & 0.69 & $(1,1,1)$ \\
\hline Burkina Faso & 1970-2013 & 1.76 & $-0.46^{* *}$ & 0.00 & 0.12 & 0.24 & $(1,1,0)$ \\
\hline Cameroon & 1970-2013 & 0.42 & -0.05 & 0.00 & -0.007 & 0.03 & $(1,1,1)$ \\
\hline Chad & 1981-2013 & 1.68 & $-0.37^{* *}$ & -0.00 & 0.036 & 0.22 & $(0,1,1)$ \\
\hline Egypt & 1970-2013 & 0.15 & $-0.37^{* *}$ & 0.00 & $0.34^{* *}$ & 0.29 & $(1,1,1)$ \\
\hline Gabon & 1970-2013 & 0.97 & $-0.33^{* *}$ & -0.00 & $0.19^{* *}$ & 0.23 & $(1,1,0)$ \\
\hline Guinea-Bissau & 1990-2013 & -1.11 & $-0.86^{* *}$ & 0.00 & $0.99^{* *}$ & 0.34 & $(1,1,1)$ \\
\hline Guyana & 1981-2013 & 0.83 & -0.28 & 0.00 & 0.11 & 0.27 & $(1,1,1)$ \\
\hline Indonesia & $1990-2013$ & 1.85 & $-0.22^{* *}$ & 0.00 & -0.07 & 0.50 & $(0,1,1)$ \\
\hline Jordan & 1970-2013 & -0.10 & $-0.42^{* *}$ & 0.00 & $0.43^{* *}$ & 0.14 & $(1,1,1)$ \\
\hline Kuwait & 1975-2013 & 1.21 & $-0.41^{* *}$ & 0.00 & $0.25^{* *}$ & 0.41 & $(1,1,1)$ \\
\hline Lebanon & 1981-2013 & $5.65^{* *}$ & $-1.13^{* *}$ & $0.00^{* *}$ & $0.44^{*}$ & 0.54 & $(1,1,1)$ \\
\hline Libya & 1970-2013 & $2.67^{* *}$ & $-1.21^{* *}$ & $0.00^{* *}$ & $0.63^{* *}$ & 0.60 & $(1,1,1)$ \\
\hline Malaysia & 1970-2013 & $1.65^{* *}$ & $-0.34^{* *}$ & $0.00^{* *}$ & 0.09 & 0.27 & $(1,1,1)$ \\
\hline Mali & 1981-2013 & $1.93^{*}$ & $-0.62^{* *}$ & -0.00 & 0.28 & 0.31 & $(1,1,1)$ \\
\hline Mauritania & 1980-2013 & 1.23 & $-0.49^{* *}$ & 0.00 & 0.28 & 0.23 & $(0,1,1)$ \\
\hline Morocco & 1970-2013 & $6.34^{* *}$ & $-0.85^{* *}$ & 0.00 & $-0.12^{*}$ & 0.64 & $(1,1,0)$ \\
\hline Niger & 1970-2013 & $1.94^{* *}$ & $-0.59^{* *}$ & $0.00^{* *}$ & 0.19 & 0.32 & $(0,1,1)$ \\
\hline Nigeria & 1970-2013 & $2.79^{* *}$ & $-0.61^{* *}$ & $0.00^{* *}$ & 0.15 & 0.28 & $(1,1,1)$ \\
\hline Oman & 1980-2013 & 2.52 & -0.15 & 0.00 & -0.14 & 0.07 & $(0,1,2)$ \\
\hline Pakistan & 1970-2013 & $0.87^{*}$ & $-0.38^{* *}$ & 0.00 & 0.22 & 0.16 & $(1,1,0)$ \\
\hline Senegal & 1970-2013 & 0.59 & -0.17 & $0.00^{* *}$ & 0.07 & 0.13 & $(1,1,1)$ \\
\hline Syria & 1970-2013 & $2.98^{* *}$ & $-0.37^{*}$ & 0.00 & -0.07 & 0.24 & $(1,1,1)$ \\
\hline Togo & 1970-2013 & $3.82^{* *}$ & $-0.81^{* *}$ & $0.00^{* *}$ & 0.12 & 0.46 & $(1,1,1)$ \\
\hline Turkey & 1970-2013 & $4.08^{* *}$ & $-0.65^{* *}$ & $0.00^{* *}$ & 0.12 & 0.39 & $(1,1,1)$ \\
\hline Uganda & 1990-2013 & -1.09 & $-0.84^{* *}$ & -0.00 & $1.00^{* *}$ & 0.34 & $(1,1,1)$ \\
\hline
\end{tabular}

*Statistical significance at $10 \%$ level. ${ }^{* *}$ Statistical significance at $5 \%$ level. 
Table 5

Intertemporal Elasticity of Substitution

\begin{tabular}{|c|c|c|c|c|}
\hline \multirow{2}{*}{ Country } & \multirow{2}{*}{ Time Period } & \multicolumn{3}{|c|}{ Estimate of Intertemporal Elasticity of Substitution } \\
\hline & & 2SLS & LIML & GMM \\
\hline Algeria & 1974-2013 & 0.33 & 0.45 & 0.33 \\
\hline Bangladesh & 1981-2013 & -0.44 & -0.50 & $-0.35^{* *}$ \\
\hline Benin & 1981-2013 & -0.08 & -0.51 & -0.19 \\
\hline Burkina Faso & 1970-2013 & -0.77 & -1.59 & -0.15 \\
\hline Cameroon & 1970-2013 & -0.60 & -1.93 & -0.45 \\
\hline Chad & 1981-2013 & -0.27 & -0.38 & -0.25 \\
\hline Egypt & 1970-2013 & 0.017 & 0.018 & 0.018 \\
\hline Gabon & 1970-2013 & -1.54 & -1.61 & -1.46 \\
\hline Guinea-Bissau & 1990-2013 & 0.095 & 0.15 & -0.048 \\
\hline Guyana & 1981-2013 & 0.18 & 0.19 & $0.16^{*}$ \\
\hline Indonesia & 1990-2013 & -0.03 & -0.11 & -0.10 \\
\hline Jordan & 1970-2013 & -0.32 & -0.38 & -0.31 \\
\hline Kuwait & 1975-2013 & 0.54 & 0.53 & 0.55 \\
\hline Lebanon & 1981-2013 & $0.37^{*}$ & $0.38^{*}$ & 0.34 \\
\hline Libya & 1970-2013 & 1.92 & 4.09 & 1.31 \\
\hline Malaysia & 1970-2013 & -2.71 & -5.49 & -3.05 \\
\hline Mali & 1981-2013 & 0.11 & 0.16 & 0.06 \\
\hline Mauritania & 1980-2013 & -0.04 & -0.06 & 0.07 \\
\hline Morocco & 1970-2013 & 0.04 & 0.06 & 0.17 \\
\hline Niger & 1970-2013 & -0.58 & -0.69 & -0.75 \\
\hline Nigeria & 1970-2013 & -0.70 & -2.08 & -0.83 \\
\hline Oman & 1980-2013 & -3.12 & -3.87 & -2.90 \\
\hline Pakistan & 1970-2013 & -0.18 & -0.19 & $-0.17^{*}$ \\
\hline Senegal & 1970-2013 & -0.49 & -1.15 & -0.15 \\
\hline Syria & 1970-2013 & 0.61 & 0.69 & 0.60 \\
\hline Togo & 1970-2013 & -1.19 & -1.92 & -1.29 \\
\hline Turkey & 1970-2013 & 0.02 & 0.02 & 0.03 \\
\hline Uganda & 1990-2013 & 0.47 & 8.23 & 0.15 \\
\hline
\end{tabular}

*Statistical significance at $10 \%$ level. ${ }^{*}$ Statistical significance at $5 \%$ level.

Lagged nominal interest rate, lagged real interest rate and lagged change in log consumption are used as instruments. 